Politik Ekonomik Kuram 2019, Cilt 3(1), 19-37

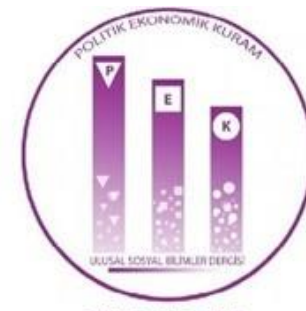

Cilt 3(1) 2019
Politik Ekonomik Kuram

Dergi Web Sitesi: http://dergipark.gov.tr/pek

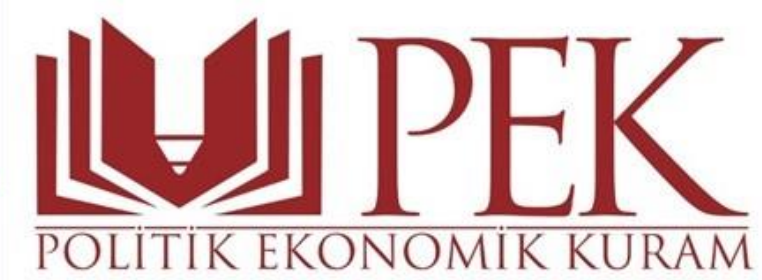

Türkiye’de Yoksulluk ve Çocuk İşçiliği İlişkisi Üzerine Bazı Tespitler ${ }^{1}$

Pelin SOMEL ${ }^{2}$

\title{
Makale Bilgileri
}

Makale Geçmişi:

Makalenin Yüklendiği Tarih: 15.04.2019

Makalenin Kabul Edildiği Tarih: 29.05.2019

Anahtar Kelimeler: Yoksulluk, Çocuk İşçiliği, Çocuk Yoksulluğu.

${ }^{1} \mathrm{Bu}$ çalışma Kocaeli Üniversitesi, SBE, Çalışma Ekonomisi ve Endüstri İlişkileri Bölümünde hazırlanan “Türkiye'de Yoksulluk Kapsamında Çocuk İşgücü” başlıklı yüksek lisans tezine dayanmaktadır.

${ }^{2}$ Kocaeli Üniversitesi, SBE, Çalışma Ekonomisi ve Endüstri İlişkileri Bölümü Yüksek Lisans Öğrencisi, İletişim somelpelin@gmail.com 


\section{Özet}

Dünyanın birçok yerinde insanlar yoksulluk içinde yaşamaktadır. Yoksulluk olgusu ülkelerin gelişmişlik düzeyine göre farklılaşsa da sisteme ilişkin bir sorun olarak karşımıza çıkmaktadır. Yoksulluk probleminin çocuklar üzerinde etkileri daha derin şekilde görülmekte ve çocukların fiziksel ve zihinsel gelişimleri olumsuz şekilde etkilenmektedir. Genellikle çocukluk döneminde yoksulluğa maruz kalan çocuklar gelecekte de yoksullukla karşı karşıya gelebilmektedir. Böylece yoksulluk nesilden nesile aktarılarak devam eden bir sorun olarak karşımıza çıkmaktadır.

Yoksul aileler perspektifinden bakıldığında çocuk işçiliği aile gelirine katkı sağladığı için çocuklar gelir kaynağı olarak görülmektedir. Bu durum çocuk işçiliğinin önlenmesi sürecindeki en önemli engellerden biridir. Çocuk işçiliğinin en kötü şartlarda gerçekleştiği hali bugünün çocuklarının geleceğin yetersiz ve yoksul bireylerine dönüşmesine sebep olmaktadır. Bu sorun sadece yoksul ailelere özgü değil, toplumun genelini ilgilendiren önemli bir sosyal gerçekliktir. Bu çalışmada Türkiye’deki çocuk yoksulluğu ve düzeyi araştırılarak, dünyada çocuk yoksulluğuna ilişkin güncel çözüm önerilerinin Türkiye'de uygulanabilme imkânı ana hatlarıyla tartışılmıştır.

\section{Poverty and Some Observations on Child Labor Relations in Turkey}

\section{Abstract}

In many parts of the World people live in poverty. Although poverty varies according to the level of development of countries, it is basically a problem. Children feel the deepest form of poverty and the physical and mental development of poor children is negatively affected. Children who are often exposed to poverty in childhood are faced with poverty in the future. So, poverty is an ongoing problem that has been transferred from generation to generation.

As child labour contributes to family income, poor families see their children as a source of income. This is an important element for child labour. The situation in which child labour occurs in the worst conditions causes the children of today to turn in to the poor and poor people of the future. This problem is not only peculiar to poor families, but also an important social reality that concerns the public. In this study, the solution proposals for child poverty in the World and child poverty and level were investigated in Turkey.

Keywords: Poverty, Child Labor, Child Poverty 


\section{Giriş}

Türkiye' de TÜİK verilerine göre 15 milyon 247 bin çocuk vardır. Bu çocukların 890 bini 2006 verilerine göre çalışmaktadır. Bu sayı 2012 yılında 893 bine yükselmiştir. (TÜİK, 2013 ).Yine TUİK Hane halkı işgücü araştırması sonuçlarına göre; 2017 yılında 15-17 yaş grubundaki çocukların işgücüne katılma oranı \%20,3 olarak belirtilmiştir( TUİK ,2018). Yine DİSK' in 2015 yılında hazırladığı Türkiye'de çocuk işçiliği gerçeği raporuna göre 1999-2006 yıllarında çocuk istihdam oranı 2 milyon 270 binden 890 bin düzeyine düşmüşken 2006-2012 y1llarına gelindiğinde yaşanan düşüşün yükselişe geçtiği ve 893 bin' e ulaştığı aktarılmaktadır.2015 yılına gelinde ise \%56'yı bulan çocuk istihdamı göze çarpmaktadır. Bu durumun sebebi temelde yoksulluk ve eğitim politikalarındaki eksikliklerin çocuk işçiliğini besleyen temel unsurlar olarak karşımıza çıkmasına sebep olmaktadır. Eğitsel, sosyal kültürel ve fiziksel gelişim süreçlerini sekteye uğratan bu sorun çocuk işçilerin ücretsiz ya da ucuz emek gücü olarak sömürüye açık bir hale gelmesine sebep olmaktadır. Bu durumun önüne geçmek için dünya çapında birçok proje yürütülmektedir. Bunun en belirgin örneği olarak ILO'nun asgari yaşam sözleşmesi ve çocuk işçiliğinin En kötü biçimlerinin belirlenmesine yönelik oluşturulan (IPEC) projesi ele alınabilir.

Çocuk işçiliği, yoksulluk ve güvencesizlik zeminde yükselen istihdam stratejilerinin yapısal olarak ürettiği bir sonuç olarak görülmektedir (DİSK :2015). Dolayısıyla bu çalışmamızda ki amaç tespit edilen veriler 1şığında Türkiye 'de çocuk işçiliğini, yapılan mücadeleyi ve gelinen noktayı araştırmaktır.

Türkiye' de yoksulluk, eğitim imkanlarına ulaşmada sıkıntılar, çocuk işçilerin ucuza çalıştırılması, çarpık kentleşme, çocuk işçi sorununa işveren ve ailelerin bakış açısı ve devletin yetersiz denetimleri çocuk işçi sorununu güçleştirmektedir. Araştırmada, Dünyada ve Türkiye' deki çocuk işliği konusunda yapılan çalışmalardan söz edilmekte çözüm önerileri sunulmaktadır

\section{Yoksulluk, Çocuk ve Çocuk İşçiliği}

İnsanlık tarihi boyunca, farklı dönemlerde farklı kültürlerde, farklı coğrafyalarda, hatta farklı coğrafyaların farklı bölgeler ve kesimlerinde çocuk ve çocukluk dönemlerine farklı anlamlar 
yüklenmiştir. İlk insan topluluklarından günümüz toplumlarına değin tüm örgütlenme biçimleri çocuğa ve çocukluk dönemine farklı şekillerde yaklaşmıştır. Toplumlar dönüştükçe, çocuk ve çocukluk dönemine olan yaklaşım da dönüşmüştür. Bu sebeple çocuk ve çocukluk dönemi iç içe geçmiş birlikte ele alınması gereken kavramlardır. Dolayısıyla çocuk kavramının çocukluk döneminin algılanışıyla şekillendiği ileri sürülebilir. Toplumların sosyal, kültürel, ekonomik evrimleri, bilim ve teknolojinin gelişmesi sonucunda bu kavramlar farklı boyutlarıyla birlikte ele alınmaya başlamıştır.

Çocukluk, bilim insanlarının, fillozofların, dini önderlerin, devlet yöneticilerinin ve çocuklarla ilgilenen hemen her kurumun kendi bakış açısını ortaya koyarak tanımlamaya çalıştığı özel bir dönemdir. Yaşamın doğal ve değişmez dönemlerinden biri olan çocukluk döneminin, toplumsallaşma ile ilişkili bir süreç olduğu, diğer toplumsal süreçler gibi toplumun hâkim norm ve değerlerinden etkilendiği belirtilmektedir. Çocuk ve çocukluk kavramları öncelikle, uzun y1llar boyunca yetişkin olunmayan ve kişilerin söz konusu dönemde sağlıklı şekilde kendi kararlarını alamadıkları biyolojik bir döneme işaret etmektedir. İnsan hakları konusunda yapılan çalışmalar, teknolojik gelişmeler ve hümanist görüşler çerçevesinde bugünkü çocuk ve çocukluk kavramlarının temeli oluşmuştur (Sağlam-Aral, 2016: 44).

Tanilli, her uygarlığın belli bir iktisadi yapının biçimlendirdiği bir değerler sistemi olduğunu söylemektedir. Yine iktisadi yapının insanların doğayla mücadelesini ve o mücadelenin ortaya çıkardığı ilişkileri içine aldığını, insanların yaşamak ve bununda ötesinde, "doğayı aşabilmek" için çalışıp üretmek, bunun içinde bir takıp üretim araçları kullanmak, çalışmak zorundadır (Tanilli, 1981: 4). İnsanların doğayı dönüştürerek, hayatta kalma mücadelesinin bir aşaması olarak yerleşik hayata geçiş gerçekleşmiştir. Avcı-toplayıcılıkta olduğu üzere gündelik çözümler, artan insan nüfusunun gelişen ihtiyaçlarını karşılamakta yetersiz kalınca üretme ihtiyacı doğmuştur. Üretme ihtiyacının sonucu olarak tarlalar ekilip biçilmeye başlanmış, bu tarlalarda çalışacak emek gücüne ihtiyaç ortaya çıkmıştır. Bunun sonucunda çocuklar tarlalarda çalıştırılmaya başlanmıştır.

Harari (2015:91), tarım devriminin insanlık için ileriye doğru atılmış büyük bir adım olarak gösterilse de avcı toplayıcıların doğanın sınırlarına daha çok hâkim olduklarını aktarmaktadır. Bununla birlikte tarım devrimi yeni ve kolay bir yaşam biçimi sağlamaktan ziyade, çiftçilere daha zor ve daha az tatmin edici bir yaşam oluşturmuştur. Tarım devrimi insanlığın elindeki 
toplam gıda miktarını kesin olarak artırmış, ancak daha iyi bir beslenme veya daha iyi bir yaşantı yaratmadığını ifade etmiştir. Bu durum nüfus patlamasına yol açmış, seçkin bir kesim yaratmıştır. Çiftçiler kötü besinler ve kötü şartlarla baş başa kalmıştır (Harari, 2015: 91). Bu tablo, çocuklarında emek gücü olarak algılanmasına sebep olmuştur. Öte yandan salt tarım toplumları değil, sanayi toplumları da çocukları işgücü olarak görmüştür. Çocuklar burjuvazinin emek maliyetini minimize etme isteği çerçevesinde çalışmak zorunda kalmışlardır. Bu durum ailenin de çocuk ve çocukluk dönemini algılayışını şekillendirmiştir. Tarım toplumlarından sanayi devrimine, sanayi toplumundan günümüzün post-modern anlayışına kadar ki toplumsal değişim sürecinde çocukluk süreci gerek çocukların aileleri gerekse hâkim sınıflar tarafindan her zaman sömürüye açık korumasız yapısı istismar edilmiştir. Özellikle yoksul ailelerin çocukları gerek ailenin gerekse sermayenin kâr amacıyla kullandığı bir olgu olarak günümüzde de geçmişte de temel bir sorun olarak karşımızda durmaktadır.

Sanayi devrimiyle beraber çalışma sürecinin evin sınırları dışında gerçekleşme başlaması, çalışma koşulları ile birlikte çocuk işçiliğinde de ciddi dönüşümlere sebep olmuştur. Aile gelirine katkı sağlamak ve zamanla bir meslek edinmek için çalışan çocuklar ucuz işgücü olarak görülerek sömürüye açık bir hale gelmiştir. Kapitalist üretim biçiminin ana üretim merkezleri olan fabrikaların ucuz emek gücü talebi karşısında çocuk emeği kullanımı artmış, vasıfsız sömürüye açık bir hale gelmiştir.

Çocuk işçiliği kavramı ise çocuğun çalışıp çalışmamasından ziyade, çalışan çocukların faaliyetlerinin hangilerinin sosyalizasyon ve eğitim, hangilerinin bunları engelleyici ve sömürücü olduğu yönünde değerlendirilmesi gerektiği vurgularıyla öne çıkmıştır. Çocuk çalışmasıyla ile çocuk işçiliği arasındaki temel farklar, çocuk işçiliğini oluşturan temel unsurları olarak iş sözleşmesine dayanarak çalışma, herhangi bir işte çalışma, karşılık uğruna çalışma ve işverene bağımlı olarak çalışmak şeklinde tanımlamıştır. Bu bağlamda çocuk işçi, "çocukluk dönemi içinde, bir hizmet akdine dayanarak herhangi bir işte ücret karşılığı çalışan kişi” olarak tanımlanmıştır (Çöpoğlu, 2018: 368).

Çalışan çocuk kavramı ise, çocuk çalışması ve çocuk işçiliğini de içinde barındıran bir üst kavramdır. Dolayısıyla çocuk çalışması ile çocuk işçiliğini birbirinden ayırmak gerekir. Çalışan çocuk denildiğinde, çocuğun eğitimini, fiziksel, zihinsel, duygusal, ahlaksal ve sosyal 
gelişimini olumsuz yönde etkilemeyen çalışmalar ifade edilmektedir. Buna karşın Fişek (2010: 24) çocuk işçiliğini, çocuğun eğitimini, fiziksel, duygusal, zihinsel, ahlaksal ve sosyal gelişimini olumsuz yönde etkileyen çalışmalar olarak belirtilmektedir. Buraya kadar ki açıklamalardan hareketle ailenin gelir düzeyinin, çocuk işçiliğinin belirleyici bir unsuru olduğu anlaşılmaktadır. Dolayısıyla konunun yoksulluk boyutu üzerine düşünmek gerekmektedir.

Yoksulluk üzerine gerek sosyal bilimciler gerekse de DB vb. Uluslararası kuruluşlar tarafından yapılan çalışmalara dayalı geniş bir literatür oluşmuş olsa da yoksulluğun nasıl ölçüleceğine dair bir mutabakat söz konusu değildir. Tüm dünya ülkelerinde varlığını sürdüren bir olgu olan yoksulluk, gelişmiş, gelişmekte olan ya da az gelişmiş ülkelere göre değişmektedir. Yine yoksulluk, içinde bulunulan ülkelerde ise yerleşim yerine, cinsiyete vb. faktörlere göre farklılıklar gösterebilir. Dolayısıyla bu noktada üzerinde uzlaşmaya varılmış yoksulluk ölçütlerinden söz etmek gerekmektedir.

TUIKK (21867 sayılı Haber Bülteni Metaveri) kapsamındaki tanımlara göre yoksulluk araştırmaları hane halkı bütçe anketlerine dayandırılmaktadır. Her yıl 2002 yılından beri düzenli olarak anketler yapılmaktadır. Bu kaynağa göre yoksulluk iki şekilde anlatılmaktadır. Dar çerçevede düşünülecek olursa yaşamını sürdüremeyecek ve barınacak yeri olamama durumu diye tanımlanırken; geniş anlamda, ancak yaşamını sürdürebilecek barınacak yer bulabilecek kadar bir düzeyi yoksulluk olarak tanımlamıştır. Yine mutlak yoksulluk ve göreli yoksulluk kavramlarından söz edilmektedir. Mutlak yoksulluk, hane halkı veya bireyin yaşamını sürdürebilecek asgari yaşamını sürdürebilecek refah düzeyinde olamaması durumu iken göreli yoksullukta ise bireylerin asgari refah düzeyinin belli bir oranının altında gelir ve harcamaya olmasıdır denmektedir. Refah ölçüsü olarak da amaca göre harcama veya gelir düzeyi seçilebilir. Yoksulluk açığı yoksulluğun derecesi hakkında bilgi vermektedir. Bir kişinin yoksulluk açığı "yoksulluk çizgisi ile geliri arasındaki farka" eşittir. Yoksulluk açığı ise toplumdaki ortalama yoksulluk açığının yoksulluk çizgisine oranına eşittir. Yoksulluk açığının 100'e yaklaşması yoksulluğun derecesinin çok fazla olduğunu, küçülmesi ise yoksulluk risk derecelerinin daha az olduğunu ifade etmektedir (TÜIK, hane halkı kullanılabilir fert gelirine göre hesaplanan yoksul sayıları, yoksulluk oranı ve yoksulluk istatistik verilerine göre 20062017). Öznel yoksulluk kavramı, ise Coşkun’ a (Coşkun,2012:184) göre toplum tarafından belirlenen duruma işaret etmektedir ve yapılan anketler aracılığıyla yoksulluk sınırının belirlendiği yoksulluk türüdür. Gelir düzeyi ve refah düzeyi arasında bir bağ kurularak yoksulluk çizgisi hesaplanır. (Coşkun :2012, 184) İnsani yoksulluk ise katlanabilir bir yaşam 
için gerekli firsat ve seçenekleri ifade eden bir yoksulluk türü olarak tanımlanmıştır. Gelirle ilişkilendirilmeyen bu yoksulluk kavramında sağlık hizmetlerine, temiz su kaynaklarına, eğitim hizmetlerine ulaşılamamaktan yani sosyal ve kültürel imkanlara sahip olmaktan söz edilmektedir (Aktan, 2002:7). Burada amaç yoksulluk verilerinin tespit edilmesi yani yoksul olan ve olmayanın ayrılmasıdır. Yani aradaki çizgiyi tespit etmektir.

Mutlak yoksulluk sınırının, yaşam standartlarıyla bağlantılı olduğu ileri sürülebilir. Buna göre belirli bir yaşam standardının altında kalanlar yoksul olarak adlandırılır. Göreli yoksulluk sınırı ise toplam nüfusunun belirli bir oranının veya medyan gelirin yarısından az gelir elde edenlerin yoksul olarak kabul edilmesi demektir. Öznel yoksulluk sınırı ise yapılan anket çalışmalarında hane halklarının asgari ihtiyaçlarını karşılayabilmeleri için gerekli asgari gelir miktarının düzeyi hakkında vermiş oldukları yanıtlardan oluşmaktadır (Kulaksız, 2014: 94).

ILO’ya göre özellikle kuşaklararası yoksulluk döngüsünün kırılması, tam istihdam ve iş firsatları yaratmayı gerektirmektedir. Düzgün ve üretken işlerin yoksulluğu azaltmada kilit rol oynayacağı fikrinin, ILO yaklaşımının ana hedefi olduğu söylenebilir (ILLO)

\section{Türkiye'de Yoksulluk ve Çocuklar}

Türkiye'nin en önemli toplumsal sorunlarından biri yoksulluktur ve 2009 TUİK rakamlarına göre12 milyon 751 kişi mutlak yoksulluk sınırının altında yaşamaktadır. (Kulaksız, 2014:98) $\mathrm{Bu}$ kesimler arasında göçmenler, kadınlar, yaşlılar ve çocuklar vardır. Gelir eşitsizliklerinin artması ve eşitsizliklerin kalıcılaşması, çocuk yoksulluğunun nesiller arası aktarılmasına neden olmaktadır.

Yoksulluk kavramını incelerken gelir dağılımı ve gelir eşitsizlikleri kavramlarını da incelemek gerekir. (Çalışkan,2010: 92) araştırmasında gelir dağılımını, belirli bir dönemde üretilen milli gelirin, bireyler, hane halkları, toplumsal guruplar arasında bölünmesidir diye tanımlamaktadır. Gelir dağılımı fonksiyonel, sektörel, bireysel (hane halkı), ikincil gelir dağılımı olarak sinıflandırılabilir.

Bireysel gelir dağılımı, milli gelirin toplumu oluşturan birey ya da hane halkları arasındaki dağılımını gösterir. Bireyin bu gelirde aldığı pay ücret, rant, faiz vs. olabilir. Bireysel gelir 
dağılımında hane halkları arasındaki eşit olmayan dağılım, gelir eşitsizliğini gündeme getirmektedir.

Bölgesel gelir dağılımı, ülkenin gelişmiş ve az gelişmiş bölgeleri arasında farkı açığa çıkarmak için kullanılır.

Sektörel gelir dağılımın da ise, milli gelirden pay alan tarım ve sanayi sektöründeki farkları ortaya çıkarır denmektedir. Ülkenin gelişmişliği sanayi sektöründeki artışla tanımlanır.

İkincil dağılımda ise bireylerin elde ettikleri ilk gelir ile son gelir arasındaki farktır. (yeni vergiler vs. )

Gelir dağglımını etkileyen faktörler ülkenin ekonomik yapısı, fırsat eşitliği, ekonomi politikaları, sektöre dağılım, emek piyasasının örgütlenme biçimidir ve işsizliktir. İşsizlik yoksulluğu doğurur. İstihdamın artırılması, gelir eşitsizliğinin dengelenmesi yoksullukla mücadelede önemli bir adımdır.

Gelir eşitsizliğini ölçmede yüzdelik dilimleme, Lorenz eğrisi ve Gini katsayısı kullanılır. Yüzdelik dilim gelir eşitsizliğini ölçmede iyi bir yöntem olarak tanımlanmaktadır. Millî gelirden pay alan hane halkları yüzdelik dilimlere bölünerek, en yüksek ve en düşük gelirli olanlar siralanır.

Lorenz Eğrisi ise milli gelirin onu elde eden nüfus arasındaki gösteren ölçme aracıdır. Grafikte yatay eksen nüfusun birikimli payını, dikey eksen ise gelirin birikimli payını gösterir. Gelirin tam eşit dağılması halinde köşegen çizgi olan mutlak eşitlik doğrusu ile çakışır. Gini katsayısı ise Lorenz Eğrisinden hesaplanır. Mutlak eşitlik doğru ile eğri arasında kalan alanın, mutlak eşitlik doğrusu altında kalan alana oranı Gini katsayısıdır.

Tablo 1: Lorenz Eğrisi 


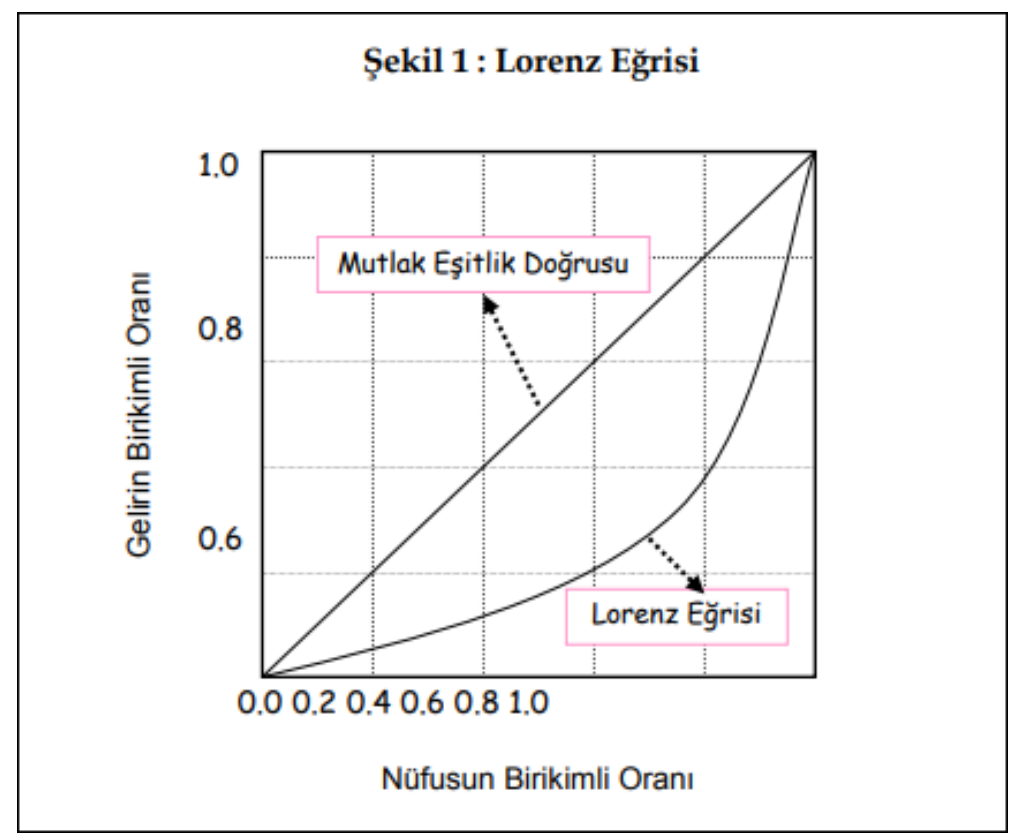

(Çalışkan,2010: 92- 98).

29 Mayıs 2018 Disk Raporuna göre Gini katsayısı 0 ile 1 arasında değer alıp 1'e yaklaştıkça gelir dağılımı bozulmakta, 0'a yaklaştıkça düzelmektedir.

Değerler 0,200 ile 0,500 arasında seyretmektedir.

Tablo 2 'de görüldüğü gibi 2005'te 0,380düzeyinde olan Gini katsayısı 2006' da 0,428'e yükselmiş, daha sonra inişli çıkışlı bir seyir izleyen Gini katsayısı 2014 yılında 0,391'e gerilemiş ancak sonra tekrar bozularak 0,404seviyesine yükselmiştir. Gelir eşitsizliğinin yüksek seviyelerde olduğu görülmektedir.

Tablo 2: Türkiye Gelir Eşitsizliği-Gini Katsayısı (2005-2016)

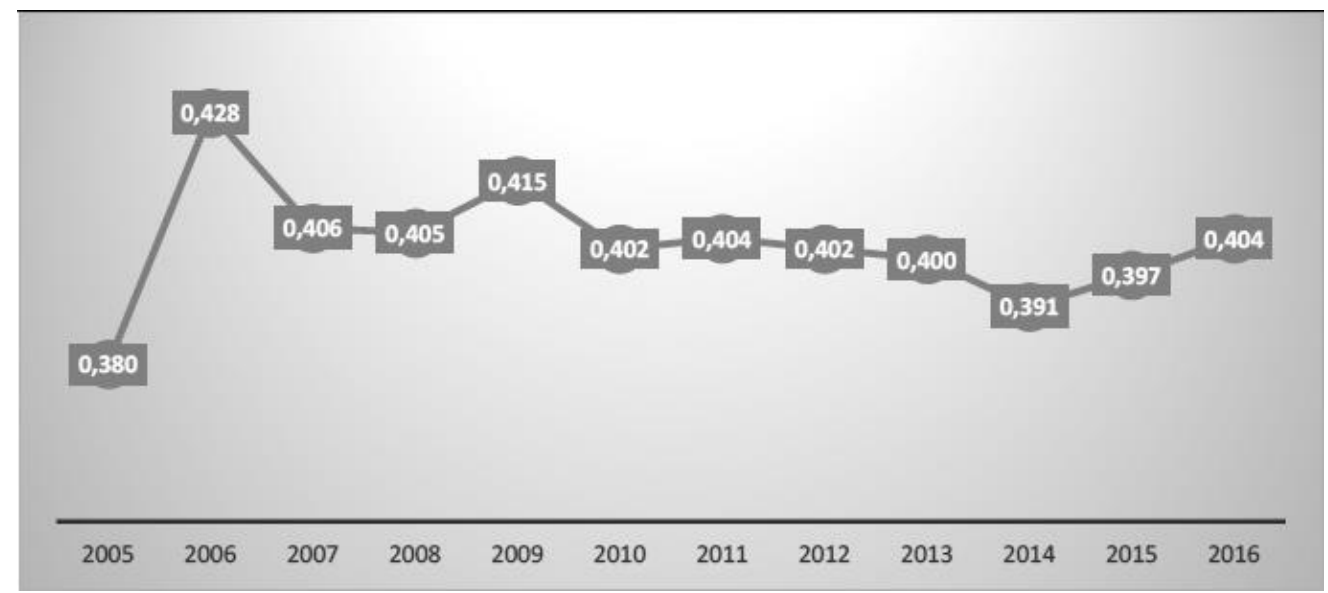

(Disk ,2019) 
Türkiye'de hane halkı kullanabilir fert gelirine göre yapılan araştırma sonuçları ise aşağıdaki tabloda görülmektedir.

Tablo 3: Hane halkı Fert Geliri ve Eğitim Durumuna Göre Yoksulluk Oranı

\begin{tabular}{|c|c|c|c|c|c|c|c|c|c|c|c|}
\hline \multicolumn{12}{|c|}{ Eşdeğer hanehalkı kullanılabilir fert gelirine ve eğitim durumuna göre yoksul sayıları ve yoksulluk oranı, Türkiye, 2006-2017 } \\
\hline \multicolumn{12}{|c|}{ [15 yaş ve üstü - 15 years or over] } \\
\hline \multirow[b]{2}{*}{$\begin{array}{l}\text { Yillar } \\
\text { Years } \\
\end{array}$} & \multirow[b]{2}{*}{$\begin{array}{r}\text { Yoksulluk } \\
\text { riski } \\
\text { Risk of } \\
\text { poverty } \\
\end{array}$} & \multicolumn{5}{|c|}{$\begin{array}{c}\text { Yoksul sayısı (Bin kişi) } \\
\text { Number of poors (Thousand person) }\end{array}$} & \multicolumn{5}{|c|}{$\begin{array}{c}\text { Yoksulluk oranı (\%) } \\
\text { Poverty rate (\%) }\end{array}$} \\
\hline & & $\begin{array}{r}\text { Okur-yazar } \\
\text { olmayanlar } \\
\text { Illiterate } \\
\end{array}$ & $\begin{array}{r}\text { Bir okul } \\
\text { bitirmeyenler } \\
\text { Literate with } \\
\text { no degree } \\
\end{array}$ & $\begin{array}{r}\text { Lise altı } \\
\text { eğitimliler } \\
\text { Less than } \\
\text { high school } \\
\end{array}$ & \begin{tabular}{|r|} 
Lise ve \\
dengi okul \\
mezunları \\
High school \\
or equivalent \\
\end{tabular} & \begin{tabular}{|r|} 
Yükseköğretim \\
mezunları \\
Higher \\
education \\
\end{tabular} & $\begin{array}{r}\text { Okur-yazar } \\
\text { olmayanlar } \\
\text { Illiterate } \\
\end{array}$ & \begin{tabular}{|r|} 
Bir okul \\
bitirmeyenler \\
Literate with \\
no degree \\
\end{tabular} & $\begin{array}{r}\text { Lise altı } \\
\text { eğitimliler } \\
\text { Less than } \\
\text { high school }\end{array}$ & \begin{tabular}{|r|} 
Lise ve \\
dengi okul \\
mezunları \\
High school \\
or equivalent \\
\end{tabular} & $\begin{array}{r}\text { Yükseköğretim } \\
\text { mezunları } \\
\text { Higher } \\
\text { education } \\
\end{array}$ \\
\hline \multicolumn{12}{|l|}{2006} \\
\hline & $\% 50-50 \%$ & 1969 & 1004 & 3783 & 463 & 24 & 32,8 & 27,8 & 5,4 & 14,3 & 0,7 \\
\hline & $\% 60-60 \%$ & 2486 & 1327 & 5605 & 825 & 48 & 41,4 & 36,7 & 9,7 & 21,2 & 1,3 \\
\hline \multicolumn{12}{|l|}{2017} \\
\hline & $\% 50-50 \%$ & 1451 & 843 & 3566 & 599 & 139 & 25,4 & 21,7 & 11,7 & 5,5 & 1,5 \\
\hline & $\% 60-60 \%$ & 2005 & 1200 & 5632 & 1036 & 296 & 35,1 & 30,9 & 18,5 & 9,6 & 3,3 \\
\hline \multicolumn{7}{|c|}{ Yoksulluk sınırı olarak ge lire dayalı göreli yoksulluk sınırları kullanılmıştır. } & & & & & \\
\hline
\end{tabular}

TUIKK. (2006- 2017. Hane halkı Fert Geliri ve Eğitim Durumuna Göre Yoksulluk Oranı)

Tabloya 1'e göre yoksulluğun eğitim düzeyi ile ilişkilendirilebileceği görülmektedir. Yoksulluk kalkınma sürecinde karşı karşıya olunan en önemli problemlerden biridir, bir diğer problem olarak eğitim(sizlik) öne çıkmaktadır.

Uluslararası Çalışma Örgütü (ILO) 10.Uluslararası Çalışma İstatistikleri Konferansında benimsenen temel tanım ve kavramların işgücü anketleri, Ekim 1988'den itibaren düzenli yapılmaktadır. Son istatistik çalışması 2012 yılında yapılmış olup TUİK verileri bu yıla aittir. Yine ILO, 1991 yılından itibaren çocuk işçiliğinin sona erdirilmesi programı (IPEC)'i başlatmıştır ve Türkiye'de 1992 yılında bu çalışmalara başlanmıştır. (Tuikgov.tr)

Aşağıdaki tabloda çalışan çocuklar çalışma nedenlerine göre gösterilmektedir.

Tablo 2: Çocuk İşgücü Yaş Durumu ve Nedenleri

\begin{tabular}{|c|c|c|c|c|c|c|}
\hline \multicolumn{7}{|c|}{ Yaş durumu ve nedenlerine göre (Bin ) } \\
\hline Yaş Grubu & $\begin{array}{c}\text { Hane halkının gelirine } \\
\text { katkıda bulunmak }\end{array}$ & $\begin{array}{l}\text { Hane halkının } \\
\text { ekonomik faaliyetine } \\
\text { yardımcı olmak }\end{array}$ & $\begin{array}{l}\text { İşöŏgrenmek meslek } \\
\text { sahibi olmak }\end{array}$ & Ailelerin isteği & $\begin{array}{l}\text { Kendi ihtiyaçlarını } \\
\text { karşlamak }\end{array}$ & Diğer \\
\hline Toplam & 41,4 & 28,7 & 15,2 & 6 & 6,8 & 1,8 \\
\hline 6- 14 & 29,8 & 48,6 & 5,5 & 12 & 3,1 & 1 \\
\hline $15-17$ & 46.9 & 19 & 20,1 & 3 & 8,7 & 2,2 \\
\hline Kent & 45,5 & 10,5 & 25,3 & 4,5 & 11 & 3 \\
\hline 6- 14 & 39,2 & 29,1 & 13,9 & 8,9 & 7,6 & 0 \\
\hline $15-17$ & 46,9 & 5,9 & 28,3 & 3,1 & 11,8 & 3,7 \\
\hline Kır & 37,9 & 43,4 & 7,1 & 7,3 & 3,4 & 0,8 \\
\hline $6-14$ & 26,2 & 56,1 & 2,3 & 13,1 & 1,4 & 0,9 \\
\hline $15-17$ & 47 & 33,7 & 10,8 & 2,9 & 5 & 0,4 \\
\hline
\end{tabular}


pedagojidernegi.com (Çalışan çocuklar)

Tablodaki verilere göre çocukların \%41,4’ü salt ekonomik katkı nedeniyle çalıştırılmaktadır. Yine hane halkının ekonomik faaliyetlerine katkıda bulunmak amacına ek olarak ailelerin ekonomik faaliyetlerine yardımcı olmak amacının varlığı, söz konu faaliyetlerde işçilere asgari seviyede bir ücret ödemek yerine çocuğun çalıştırılması durumuna işaret etmektedir.

\section{Türkiye’de Çocuk İşçiliğini Önlemek İçin Alınan Önlemler}

Birleşmiş Milletler (BM)Uluslararası Çalışma Örgütü (ILO), BM Çocuklara Yardım Fonu (UNICEF), Dünya Bankası (DB) ve Dünya Sağlık Örgütü (DSÖ) gibi çeşitli uluslararası kurum ve kuruluşlar çocuk işçiliğine karşı faaliyetler yürütmektedir.

UNICEF ve DB Grubu hükümetlere aşağıdaki konularda çağrıda bulunmaktadır:

a- Çocuk yoksulluğunun ulusal ve bölgesel düzeylerde rutin olarak ölçülmesi ve aşırı yoksulluğa 2030 yılına kadar son verilmesine yönelik çabaların bir parçası olarak, "Yoksullukla Mücadele Ulusal Planlarında çocuklara odaklanılması,

b- Çocukları yoksulluğun etkilerinden koruyacak beslenme, sağlık, eğitim ve diğer hizmetlere ulaşılmasında yoksul ailelere doğrudan yardımcı olan nakit transferi programları da dâhil olmak üzere, çocuklara duyarlı sosyal koruma sistemlerinin güçlendirilmesi ve çocukların yoksulluk döngüsünü kendi yaşamlarında kırma firsatlarının artırılması,

c- En yoksul konumdaki çocuklara yarar sağlayan, ayrıca kuraklık, salgın hastalık ya da istikrarsızlık gibi olumsuzluklar sonucunda insanların yoksulluğa düşmelerine neden olan koşulların oluşmasını engelleyen, eğitim, sağlık, temiz su, sanitasyon ve altyapı gibi alanlardaki yatırımlara öncelik tanınması ve son olarak,

d- Politika kararlarının, ekonomik büyümenin en yoksul durumdaki çocuklara yarar sağlayacak sonuçlar verecek şekilde alınması.

$\mathrm{Bu}$ uyarılar çerçevesinde Türkiye pek çok sözleşmeyi imzalayarak ve yasal düzenlemelere gitmiştir ve çocukların çalıştırılmasına karşı mücadele eden ülkelerden bir olmuştur.

UNICEF, hükümetler arası bir kuruluştur. İlgili hükümetlerle geliştirdiği beş yıllık program ve projeleri o ülkedeki kamu, özel sektör, sivil toplum kuruluşları, üniversiteler ve medya ortakları ile birlikte uygulamaktadır. Türkiye Cumhuriyeti ile temel anlaşma 1951 yılında yapılmıştır. 
Gelişen y1llar boyunca temel anlaşmalar eylem planına dönüştürülmüştür (Unicef.org.tr) Amaç, Ülke Programı Eylem Planı'na (ÜPEP)' e göre çocuk haklarının uygulanması için yapılan çalışmaları, ulusal kalkınma politikaları ile birleştirmektir.2006-2010 yıllarını kapsayan ÜPEP 2006'da imzalanmıştır.2010 yılına kadar Türkiye' de yoksulluğun azaltılmasını hedeflemiştir. Söz konusu planda çocuklar için koruyucu ortamın geliştirilmesi, daha olumlu gelişmeleri ve korunmaları için kanunlara uyulmasının teşvik edilmesi, dikkat çeken maddelerden bazılarıdır. UNICEF, Sağlık Bakanlığı, Sosyal Hizmetler ve Çocuk Esirgeme Kurumu, Millî Eğitim Bakanlığı ile uzun soluklu çalışmalar yapılmıştır. Ayrıca ÜPEP kapsamında Tarım ve Köy işleri Bakanlığı, Devlet Planlama Teşkilatı, TUIK, Dünya Sağlık örgütü yerel medya ve özel sektör kuruluşları ile çalışılmıştır ve STK'larla da çalışmaya devam edecektir (UNICEF. org.tr, 2019). UNICEF, Türkiye Hükümeti ile 2016- 2020 yıllarını kapsayacak olan Çocuk Dostu Şehirler programı adlı ortak bir çalışma daha yürütmektedir.

Aşırı yoksulluğa 2030 yılına kadar son verilmesi ve refahın her ülkede daha adil paylaşı1ması için birlikte çalışırken, DB Grubu dünyadaki gelişmekte olan ülkelere finansman ve teknik yardımlar sağlanması açısından son derece önemli bir kaynak durumundadır. Grup, bugün eğitim ve HIV/AIDS'e karşı mücadelede dünyadaki en büyük dış finansman kaynağı; biyolojik çeşitlilik, su ve sanitasyon projelerinde de en büyük uluslararası finansman kaynağı durumundadır. Grup 189 üye ülkeyle birlikte dünyadaki en dayatıcı kalkınma sorunlarını göğüslemek üzere çalışmalar gerçekleştirmektedir

DB ve UNICEF (2016) tarafından yapılan "Aşırı Yoksulluğa İlişkin Çocuklara Odaklanma” analizine göre çocukların aşırı yoksulluk içinde yaşama olasılığının yetişkinlerin iki katı olduğu belirtilmektedir. Ayrıca dünyada 385 milyon çocuk aşırı yoksulluk içinde hayatını sürdürmektedir. Yine aynı araştırmada, beş yaşından küçük çocukların beşte birinden fazlasının aşırı yoksul ailelerde olduğu görülmektedir. Yine aynı Bu çalışmada 2013 yılında gelişmekte olan ülkelerdeki çocukların \%19,5'i kişi başına ortalama günlük gelirin 1,90 \$ ya da daha altında gelir sahibi olan ülkelerde yaşadığı bildirilmektedir. Yine DB 'nin temel araştırması olan “Yoksulluk ve Paylaşılan Refah 2016: Eşitsizliğe Karşı Mücadele Raporu'na göre 2013 yılında dünyada yarısı 18 yaşından küçükler olmak üzere 767 milyon insan günde, 1,90 \$'dan az kazanarak yaşamını sürdürmektedir. Çocuk yoksulluğu ile ilgili küresel tahminler, gelişmekte olan ülkelerin toplam nüfusunun \%83'ünü temsil eden 89 ülkeye ait verileri temel almaktadır. 
Çocuklara dönük yapılan en önemli çalışmalardan bir diğeri ILO ile yapılan sözleşmelerdir. Türkiye ILO’ya 18.07.1932 tarihine üye olmuştur. Türkiye'de ILO tarafından onaylanan 59 sözleşmeden 55'i yürürlüktedir. Üç sözleşmese ise Türkiye tarafından onaylanmamıştır. ILO sözleşmeleri 177'si teknik, dördü yönetişim, sekizi temel olmak üzere 189 adettir.

ILO’nun 182 numaralı en kötü şartlardaki çocuk işçiliğinin yasaklanması ve ortadan kaldırılmasına ilişkin sözleşmesi ILO'nun temel haklara ilişkin sekiz sözleşmesinden biridir. ILO'nun1.06.1999 tarihinde yapılan 87.Oturumunda; ulusal ve uluslararası eylemler için temel en kötü biçimlerdeki çocuk işçiliğinin yasaklanması ve ortadan kaldırılması olduğu vurgulanmıştır. Aynı zamanda en kötü biçimlerdeki çocuk işçiliğinin, ailelerin ihtiyaçlarına cevap vererek ücretsiz temel eğitimin önemine ve buna maruz çocukların bütün bu işlerden uzaklaştırılmaları gereğini ve onların rehabilitasyonlarını ve sosyal uyumlarının sağlanmasının öneminden bahsedilmiştir. Oturumda çocuk işçiliğinin, büyük ölçüde yoksulluktan kaynaklandığını ifade edilmiştir. Sözleşmenin kabul tarihi 17.06.1999'dur. Türkiye'de yürürlüğe girdiği tarih ise 2.08.2001'dir.ILO'nun 182 numaralı sözleşmesi bir acil eylem sözleşmesidir. Çocuk işçiliğinin büyük ölçüde yoksulluktan kaynaklandığını ve uzun vadeli çözümünün sosyal gelişmeye ve özellikle yoksulluğun azaltılmasına ve evrensel eğitime imkân tanıyan sürekli ekonomik büyümede yattığını kabul ederek özellikle 1930 tarihli zorla çalışma sözleşmesinde ve 1956 tarihli birleşmiş milletler kölelik ve köle ticareti uygulamaları ortadan kaldırılması ek sözleşmesinde yer verildiğini hatırlatarak kabul edilmiştir. Bu sözleşmenin 1. Maddesi bu sözleşmeyi uygulayan her ülke acil sorun olarak en kötü biçimlerdeki çocuk işçiliğinin yasaklanması ve kaldırılmasını temin edecek ivedi tedbirleri alır denmektedir.

Sosyal politikanın kritik konular biri olan çocuk emeğine ilişkin çalışmaların önemli bir noktasını hukuksal düzenlemeler oluşturmaktadır. Makal bu kapsamda en önemli görevin engelleyici, düzenleyici ve denetleyici işlevleri ile sistemin aktörlerinden biri olan devletin üzerinde olduğunu belirtmiştir. Devletlerin çoğu yasama yoluyla çocuk emeğine ilişkin koruyucu düzenlemeler yapma yoluna giderken, anayasalarında konuya ilişkin ilkelere yer verilmiş, yasa, tüzük ve yönetmelikler çıkarılmıştır. Yasama yoluyla yapılan farklı iş tipleri için en az çalışmaya giriş yaşlarını belirlemek, bazı iş faaliyetlerinde çocuk istihdamını engellemek ve buna izin verilen durumlarda da ücretler ile aralarında iş süreleri ve işçi sağlığı ve güvenliğinin de bulunduğu çalışma koşullarını koruyucu minimum standart koyarak düzenlemeye çalışmıştır. Yine Makal konuya ilişkin emek piyasasında hiçbir pazarlık gücüne 
ve kendilerini korumak için gerekli hiçbir araca sahip olmayan çocuklar açısından bu yasal düzenlemelerin önemini vurgulamıştır. (Makal, 2018 :325).

Günümüzde ise 4857 sayılı iş kanunu geçerli olup, çocuklar konusunda Ülkemizde çalışma hayatını düzenleyen ve bu kanuna göre hazırlanan uluslararası mevzuat ve normlarla uyum içerisindedir. Mevzuatla ilgili en önemli sıkıntı, tarım sektöründe işgücünün denetiminin, ancak 50'den fazla, daimî statüde, tam zamanlı işçi çalıştıran işyerlerinde yapılabilmesidir. Kanunda öncelikle "genç işçiler" ve "çocuk işçiler" ayrımına yönelik bir tanımlama yapılmıştır. Bu bağlamda 4857 sayılı İş Kanunu'na göre; on sekiz yaşından küçükler "çocuk" ve "genç işçiler" olarak iki kategoriye ayrilmaktadır (Acu,2014:30).

4857 Sayılı Kanun'u detaylı incelersek;

Bu kanun 2003 yılında yürürlüğe girmiştir.1. maddesinde belirtildiği üzere amac1, işverenler ile bir iş sözleşmesine dayanarak çalıştırılan işçilerin çalışma şartları ve çalışma ortamına ilişkin hak ve sorumluluklarını düzenlemektir. Bu kapsamda çocukların çalıştırılmasına ilişkin düzenlemeler madde 71 'de yer almaktadır. Çalıştırma yaşı ve çocukları çalıştırma yasağına ilişkin madde 71 'de2015 yılında yapılan değişiklik kapsamında (6645/38 Madde) On beş yaşını doldurmamış çocukların çalıştırılması yasaktır. Ancak, On dört yaşını doldurmuş ve zorunlu ilköğretim çağını tamamlamış olan çocuklar için;

- $\quad$ Bedensel, zihinsel, sosyal ve ahlaki gelişmelerine ve eğitime devam edenlerin okullarına devamına engel olmayacak hafif işlerde çalıştırılabilirler.

- $\quad$ On dört yaşını doldurmamış çocuklar ise bedensel, zihinsel, sosyal ve ahlaki gelişmelerine ve eğitime devam edenlerin okullarına devamına engel olmayacak sanat, kültür ve reklam faaliyetlerinde yazılı sözleşme yapmak ve her bir faaliyet için ayrı izin almak şartıyla çalıştırılabilirler.

Yine aynı madde çocuk ve genç işçilerin işe yerleştirilmelerinde ve çalıştırılabilecekleri işlerde güvenlik, sağlık, bedensel, zihinsel ve psikolojik gelişmeleri, kişisel yatkınlık ve yetenekleri dikkate alınması ve çocuğun gördüğü iş onun okula gitmesine, mesleki eğitiminin devamına engel olamaz, onun derslerini düzenli bir şekilde izlemesine zarar veremeyecek nitelikte olması gerektiğini belirtmektedir.

- $\quad$ On sekiz yaşını doldurmamış çocuk ve genç işçiler bakımından yasak olan işler 
- $\quad$ On beş yaşını tamamlamış, ancak on sekiz yaşını tamamlamamış genç işçilerin çalışmasına izin verilecek işler

- $\quad$ On dört yaşını doldurmuş ve zorunlu ilköğretim çağını tamamlamış çocukların çalıştırılabilecekleri hafif işler

- $\quad$ On altı yaşını doldurmuş fakat on sekiz yaşını bitirmemiş genç işçilerin hangi çeşit işlerde çalıştırılabilecekleri

Çalışma ve Sosyal Güvenlik Bakanlığı tarafından yine bu maddeye göre belirlenmiş;

- Zorunlu ilköğretim çağını tamamlamış ve örgün eğitime devam etmeyen çocukların çalışma saatleri günde yedi ve haftada otuz beş saatten; sanat, kültür ve reklam faaliyetlerinde çalışanların ise günde beş ve haftada otuz saatten fazla olamaz.

- $\quad$ Bu süre, on beş yaşını tamamlamış çocuklar için günde sekiz ve haftada kırk saate kadar artırılabilir.

- $\quad$ Okul öncesi çocuklar ile okula devam eden çocukların eğitim dönemindeki çalışma süreleri, eğitim saatleri dışında olmak üzere, en fazla günde iki saat ve haftada on saat olabilir.

- $\quad$ Okulun kapalı olduğu dönemlerde çalışma süreleri yukarıda dördüncü fikrada öngörülen süreleri aşamaz.

Ayrıca, Sanat, kültür ve reklam faaliyetlerinin kapsamı, bu faaliyetlerde çalışacak çocuklara çalışma izni verilmesi, yaş grupları ve faaliyet türlerine göre çalışma ve dinlenme süreleri ile çalışma ortamı ve şartları, ücretin ödenmesine ilişkin usul ve esaslar ile diğer hususlar;

- Aile ve Sosyal Politikalar Bakanlığ1

- Kültür ve Turizm Bakanlığı, Sağlık Bakanlığı

- Millî Eğitim Bakanlığg ile Radyo ve Televizyon Üst Kurulunun

Görüşleri alınarak Çalışma ve Sosyal Güvenlik Bakanlığı tarafından çıkarılacak yönetmelikle belirleneceği aktarılmıştır.

İlgili Kanun'a göre Yer ve su altında çalıştırma yasağı madde 72 ile

- Maden ocakları ile kablo döşemesi

- Kanalizasyon ve tünel inşaatı gibi yer altında veya su altında 
Çalışılacak işlerde on sekiz yaşını doldurmamış erkek ve her yaştaki kadınların çalıştırılması yasaklanmıştır.

Gece çalıştırma yasağı ise madde 73 'te ele alınmış Sanayiye ait işlerde on sekiz yaşını doldurmamış çocuk ve genç işçilerin gece çalıştırılması yasaklanmıştır.

\section{Sonuç ve Öneriler}

DİSK’in2015 yılındaki Türkiye ‘de Çocuk İşçiliği Raporuna göre; Çocuk işçiliği, insani gelişim açısından ciddi bir sorun olarak karşımıza çıkmaktadır. Dünyada her beş çocuktan biri çalışmak zorundadır. Bu çocuklar sağlıklı bir çevreden ve temel hak ve özgürlüklerden mahrum kalmaktadır. Fiziksel, sosyal, kültürel, duygusal ve eğitsel gelişimleri sekteye uğramaktadır. Bu durum çocuk işçilerin ücretsiz işçi ya da ucuz emek gücü olarak algılanarak sömürüye açık hale gelmesine neden olmaktadır. Çocuk işçiliğinin önüne geçmek için dünya birçok proje yürütülmektedir. Bunun en belirgin örneği olarak ILO’ nun “Asgari Yaşam Sözleşmesi ve En Kötü biçimlerinin belirtilmesine yönelik” oluşturulan (IPEC) projesidir. Güvencesizliğin çalışma yaşamını daha fazla baskı altına aldığı bu süreçte, kalıcı adımların atılması için emek yanlı programlara ihtiyaç duyulmaktadır. Türkiye 'de bu tip projeler içinde yer alsa da mevcut istihdam stratejileri çocuk işçiliğine çözüm bulamamaktadır.1999- 2006 yıllarında çocuk istihdam oranı 2 milyon 270 binden 890 bin düzeyine düşmüş iken bu 2006-2012 y1llarına gelindiğinde yaşanan düşüşün yükselişe geçtiği 89 bine ulaştığı görülmektedir.

Günümüzde geçerli olan 4857 sayılı İş Kanunu 18 yaşını doldurmamış çocuk ve genç işçilerin çalışabileceği işler, on sekiz yaşını tamamlamamış genç işçilerin çalışacağı işler, on dört yaşını doldurmuş zorunlu eğitimini çocukların çalışabileceği hafif işler, on altı yaşını doldurmuş fakat on sekiz yaşını bitirmemiş genç işçilerin 71. Maddesi çocuk çalıştırma yaşı ve çocukların çalıştırılma yasağına ilişkin düzenlemeler içermektedir.

2015' e gelindiğinde \%56 oranında çocuk istihdamı görülmektedir. Bu artış Türkiye' de çocuk emeğinin en kötü biçimde yaşanmasına sebep olmaktadır. Bununla beraber yoksulluk ve eğitim politikaları çocuk emeğinin acımasız döngüsünü besleyen unsurlar olarak karşımıza çıkmaktadır. Çocuk İşçiliğinin azaltılmasına yönelik artan çabalara rağmen çocuk işçiliği henüz ortadan kaldırılamamıştır ve çocuk işçilerin çok geniş kesimi tarım sektöründedir. Tarım 
sektörü en tehlikeli sektörler arasında yer almaktadır. Türkiye" de çocukların çalıştırılmasının temel nedeni olarak yoksulluk gelmektedir. 6- 17 yaş arasında çalışan çocuklardan \%39,3 okula devam ederken aynı zamanda hane halkına işine katkı sağlamak için \%24,5 çalışmaktadır. Çalışan çocuklardan \%58,7si hane halkı gelirine katkıda bulunmak için çalışmakta ve okula gitmemektedir.

TÜİK (2018) hane halkı işgücü anketlerine göre 15-17 yaş gurubundaki çocuklarda iş gücüne katıla oranı\%20,3 olarak belirtilenmiş iken 2018 yılında \%21,1' e yükselmiştir.

2012 yılında yasalaşan 4+4+4 yasası ilköğretim yası 6-13 yaş aralığına çekilmiş ilk öğretim bitiş yaşı aynı zamanda çocuk işçiliğinin yaygınlaşma yaşını fiilen 13 'e düşürmüştür. Yine esneklik başlığı altında evden ve uzaktan okumayı yasal hale getirme çabası ev içinde çalışan çocuğu ilgilendirmektedir.

Çocuk işçiliği yoksulluk ve güvencesizlik zemininde yükselen istihdam stratejileri yapısal olarak ürettiği bir sonuç olarak görülmektedir. Dolayısıyla çocuk işçiliği ile mücadele, bu strateji ile mücadeleden geçmektedir.

Burada önemli olan yoksulluk kavramı ile mücadele etmek yanında yapılan tüm yasal düzenlemeler ve tedbirlerin denetlenmesi bu konuda ailelerin bilinçlendirilmesi, eğitimin önemsenmelidir. Aynı zamanda işverenlerin bilinçlendirilmesi, çocuk işçi çalıştırması konusunda hukuki tedbirlere uyulması sağlanmalı ve hatta cezai tedbirler sertleştirilmelidir.

\section{Kaynakça}

A1rıdemir. E. 2017. Çocuk Hakları Çalışmaları. İstanbul: On iki levha.

Alper, Y.1993.Çocuk İşçilerin Sosyal Güvenlik Hakları. Bursa: Uludağ Üniversitesi.

Baştan Yılmaz, T.1994. Formel ve Enformel Sektörde Çalışan Çocuklar ve Sanayiye Etkisi. Bursa: Uludağ Üniversitesi.

Coşansu, İ.1992.Türkiye'de Çocuk İşgücünün Demografik ve Sosyo-Ekonomik Boyutları. Ankara: HacettepeÜniversitesi.

Çelik, A.2014.Avrupa Birliği Sosyal Politikası ve Türkiye. İstanbul: Kitapevi

Fisunoğlu, M.1994.Çalışan Çocukların Durumu ve Sanayiye Etkisi. Adana: Çukurova Üniversitesi. 
Güven, S.2001.Sosyal Politikanın Temelleri. Bursa: Ezgi Kitabevi.

Harari, Y.2015. Sapıens. İstanbul: Kolektif Kitap.

Işıcçı, Y.2015. Çocuk Gözüyle Türkiye'de Çocuk Hakları Sorunu: Hegem Yayınları.

İnal, K.2010. Türkiye'de Çocuk Emeği. İstanbul: Ütopya Yayınevi.

Makal, A.2018. Ameleden İşçiye: İletişim Yayıncılık.

Öztürk, 2011. Çocuk Hakları Açısından Çocuk İhmali ve İstismarı. İstanbul: Vakfı Yayınları.

Özpolat, V. 2011. Türkiye'nin Çocuk Mağduriyeti Haritası. Ankara: Pegem Yayınları.

Şirin, S. 2019.Yetişin Çocuklar. İstanbul: Doğan Kitap

Tanilli,S .1984. Yüzyılın Gerçeği ve Mirası: Say Yayınları

Urhan, B.1996.Azgelişmişlik Çocuk İstihdamı İlişkisi ve Türkiye'de Çocuk İşgücüne İlişkin Sorunlar. İstanbul: İstanbul Üniversitesi.

Aktan, M., Vural.Y.2002.Terminoloji, Temel Kavramlar ve Ölçüm Yöntemleri [online] http://www.canaktan.org/ekonomi/yoksulluk/birinci-bol/aktan-vural-yoksulluk.pdf

Acu,C.2014.Dünya'da ve Türkiye'de Çocuk, Çocuk İşgücü Sorunu Ve Çocuk [online].https://www.academia.edu/9474937/\%C3\%870CUK_\%C4\%B0\%C5\%9EG\%C3\%9 CC\%C3\%9C_SORUNU_VE_\%C3\%87OCUK_REFAHI_POL\%C4\%B0T\%C4\%B0KALAR I_Child_Labour_and_Child_Welfare_Policy_/,(Erişim Tarihi, 17.01.2018).

DiSK-AR: Türkiye'de Çocuk İşçiliği Gerçeği Raporu.2015. [online].http://disk.org.tr/wpcontent/uploads/2018/05/AKP-D\%C3\%B6neminde-Emek-DISK-RAPORU.pdf .(erişim tarihi 22.05.2019).

Coşkun.M.N.2012.Türkiye'de Yoksulluk Bölgesel Farklılık ve Yoksulluğun Profili.M.[online].https://www.econstor.eu/bitstream/10419/81643/1/72058034X.pdf(erişim tarihi 21.05.2019).

Çöpoğlu,M. 2018. Dünyada ve Türkiye'de Çocuk İşçiliği ve İşsizlik [online].http://dergipark.gov.tr/download/article-file/45756(Erişim Tarihi:6.04.2019).

Çalışkan. Ş.2010.Türkiye'de Gelir Eşitsizliği ve Yoksulluk.[online]. https://dergipark.org.tr/download/article-file/9313(erişim tarihi 22.05.2019)

Durgun.Ö.2011.Türkiye’ de Yoksulluk ve Çocuk Yoksulluğu üzerine bir inceleme [online] http://dergipark.gov.tr/download/article-file/40436 (Erişim Tarihi, 26.03.2019).

Ensari, S.2010.TUIK'inYoksulluk Analizi Üzerine [online]. http://dergipark.gov.tr/download/article-file/150757(Erişim Tarihi,2.04.2019). 
Gül Sallan, S., Kahraman, F.2015.Türkiye'de Çocuk Yoksulluğu: Gaziantep Üzerine Bir Araştırma [online]. $\quad \underline{\text { http://dergipark.gov.tr/download/article-file/86123 }}$ (Erişim Tarihi.5.04.2019).

ILO.Çocuk işçiliği raporu.2013.[online].https://www.ilo.org/ankara/areas-of-work/childlabour/lang--en/index.htm (Erişim Tarihi: 05.04.2019).

Kulaksız. Y.2014.Yoksulluk Bağlamında Çocuk İşgücü [online]. http://app.csgb.gov.tr/cdd/pdf/sayi5/files/assets/common/downloads/page0093.pdf/,(Erișim Tarihi,17.01.2018).

TUİK. 2018. Hane halkı Fert Geliri ve Eğitim Durumuna Göre Yoksulluk Oranı.Veri tabanlar1-istatistiksel tablolar- Yoksulluk istatistikleri gelire dayalı yoksulluk istatistikleri. [Online]. http://www.tuik.gov.tr/PreTablo.do?alt_id=1013 (Erişim tarihi, 21.05.2019). TUIK. 2012.Çocuk İşgücü Yaş Durumu ve Nedenleri. [online].https://pedagojidernegi.com/wpcontent/uploads/2017/10/\%C3\%87al\%C4\%B1\%C5\%9Fan-\%C3\%87ocuklar-2012.pdf(Erişim Tarihi:6.04.2019).

TUİK.YoksullukÇalışması.2015.[online] http://www.tuik.gov.tr/PreHaberBultenleri.do?id=21 $\underline{867 .}$

UNICEF ve Dünya Bankası projesi. Aşırı yoksulluğa son çocuklara odaklanma. [online]. http://www.unicef.org.tr/basinmerkezidetay.aspx?id=22695(Erişim Tarihi:6.04.2019). Üzümcü, A.Kokat,M.2014.Türkiye'deYoksulluk Gelir Dağılımı Adaletsizliği ve Yoksullukla Mücadel Sosyal Yardımların Gelişimi.[online]http://dergipark.gov.tr/download/article-

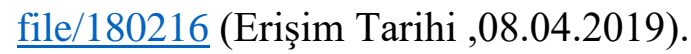

4857 Sayılı İş Kanunu [online].http://iskanunu.com/sizin-sorduklariniz/2600-genc-ve-cocukiscilerin-calisma-saatleri-ve-tatilleri/,,(Erişim Tarihi, 17.01.2018).

World Bank.(2018).Türkiye'de İnsan Sermaye Endeksi.[ONLİNE]. http://pubdocs.worldbank.org/en/354481539258948067/HCI-2pagerTUR-TR.pdf (Erişim Tarihi :06.04.2019). 